\title{
Application of Tawarruq in Islamic Banking in Malaysia: Towards Smart Tawarruq
}

\author{
Muhammad Faruq Roslan ${ }^{1}$ \\ Omar Bamahriz ${ }^{1}$ \\ Aishath Muneeza ${ }^{1}$ \\ JinZi Chu ${ }^{l}$ \\ Zakariya Mustapha ${ }^{2}$ \\ Mohamad Zabidi Ahmad ${ }^{3}$
}

\author{
${ }^{1}$ International Centre for Education in Islamic Finance \\ (INCEIF), Malaysia \\ ${ }^{2}$ University Malaya, Malaysia \\ ${ }^{3}$ CIMB Investment Bank Bhd, Malaysia
}

\begin{abstract}
The objective of the paper is to discuss the application of tawarruq in Islamic banking generally. The modus operandi of tawarruq in Islamic banking is an essential discussion in jurisdiction like Malaysia, where most Islamic banks use tawarruq to structure Islamic banking products. This paper employs a systematic literature review on best practice models and mechanism of current tawarruq application. The outcome of the research helps to understand the modus operandi of tawarruq transactions practically with a view towards understanding its future prospects in the era of Fintech. It is envisaged that this research will assist the growing understanding of the existing application of tawarruq in Islamic banking as well as its future development using technology.
\end{abstract}

Keywords: Fintech; Islamic Banking; Smart Contract; Blockchain; Tawarruq 


\section{Introduction}

Tawarruq is a contract that is often used to solve liquidity problem among market players. Its wide usage can be attributed to having a simple and convenient structure (Alkhamees, 2017). However, there has been controversy raised over the legitimacy and permissibility of the current tawarruq contract. In 2009, the Organization of Islamic Cooperation Fiqh Academy reaffirmed its position on the impermissibility of organised tawarruq (tawarruq masrafi), the main bone of contention which has become prevalent in modern Islamic banking especially for liquidity management and as a financing avenue (Majma' al-Fiqh al-Islami al-Duwali, 2009). The structure of organised tawarruq is criticised by the Fiqh Academy for lacking principles and the substance of a real trading activity. It involves simultaneous transactions between the bank (financier) and the mustawriq (customer), done implicitly or explicitly in exchange for financial obligation. This implies that both transactions (purchase and sale of the commodity) are made in effect by the financier (bank) with certain paperwork introduced to artificially include or demonstrate the use of brokers and third parties. Furthermore, some of the commodities being used for the tawarruq transactions do not fit the specifications for those that have genuine uses, are of value in the market and where (Al-Zuhaili, 1989) explains that short of these conditions will invalidate a sale contract since the object of sale will be of little or no value. However, it is important to understand that these criticisms are aimed at the current implementation of tawarruq rather than the legality, legitimacy, and substance of the classical tawarruq contract.

Transitioning from the contentious nature of implementing tawarruq, the authors are confident that fintech holds the key towards a better implementation of the contract. In fact, the market is already benefitting from the amalgamation of fintech and tawarruq, as seen in the offering of the As-Sidq tawarruq platform by Sedania As-Salam. AsSidq platform offers immediate liquidity solutions with prepaid telecommunication airtime credit as the traded commodity; while the underlying asset is intangible, it is considered permissible due to its attributes that are consistent with Shariah principles, such as beneficial to society (Ismail, et al., 2016). The usage of airtime allows certain edge over the conventional means, such as reducing handling cost and delivery cost.

The objective of the paper is to discuss the application of tawarruq in Islamic banking and provide a solution based on blockchain system. The modus operandi of tawarruq in Islamic banking is an essential discussion, as in jurisdictions like Malaysia most of the Islamic banks use tawarruq to structure the Islamic banking products. This paper employs a systematic literature review on best practice models and mechanism of current tawarruq structures, as well as a proposed future implementation of tawarruq structure.

This paper is divided into five sections. Followed by the first section that provides introduction, second section of the paper discusses the juristic debate on the permissibility of tawarruq and the developments in the application of tawarruq in Islamic banking. Section three discusses the use of tawarruq in contemporary Islamic

International Journal of Management and Applied Research, 2020, Vol. 7, No. 2 
banking while section four discusses the recommendation which is the proposed smart tawarruq model. The final section is the conclusion.

\section{Review of Juristic Debate on the Permissibility of Tawarruq}

The Arabic word tawarruq is seldom found in Arabic dictionaries and cannot be traced directly to the Arabic language. It derives from the word al-warq which refers to a minted dirham or any silver used as for the purpose of serving as a medium of exchange. Tawarruq could be the most suitable vehicle to fulfil the need for cash liquidity (Mohamad and Ab Rahman, 2014).

Technically, tawarruq involves a series of sale contracts where a buyer (al-mustawriq) buys an asset from a seller for deferred payment and thereafter sells the asset (at a low price) to a third party. This is done with no intention of making use of the purchased asset but rather with the ultimate objective of obtaining cash or liquidity at that particular time. Classical tawarruq (tawarruq al-Fiqhi) which may also be referred to as non-organised tawarruq was largely accepted and regarded as permissible by a wide range of classical scholars from the Hanbali, Shafi', Hanafi schools of thought. It should be noted however, that tawarruq in its explicit form as a contract that was not discussed directly by the classical jurists.

There are three forms of tawarruq. The first form of tawarruq occurs when an individual in need of cash purchases a commodity on credit and then discreetly sells it off to a third party. Second, where an individual in need of cash requests a loan from a trader and the trader offers to sell him a commodity on credit for its market (cash) price where the individual (mutawariq) then sells the commodity at either higher or lower than the market price to get cash at that particular time. The third form of tawarruq is similar to the second except that in this case, the trader sells the commodity to the mustawriq at a higher price than the market price due to the deferred basis of payment. It needs to be understood that the first two forms mentioned above are unanimously agreed upon by jurists and is not a bone of contention. However, it is the third form that raises opposing views from the jurists. There are three different views regarding tawarruq from the jurists, and they classify tawarruq as permissible (harus/ halal), reprehensible (makruh) and prohibited (haram).

As mentioned earlier, the tawarruq contract was not specifically mentioned during the early days of Islamic jurisprudence and was mentioned as a form of the "inah contract which was prohibited. Inah is prohibited because the commodity is sold back to the person from whom it was purchased. Inah consists of two parties which the seller is the first party who buys the commodity at certain price, and the buyer is the second party who buys the commodity at a higher price, and on deferred payment. On the contrary, tawarruq consists of three parties. If the second transaction is to a third party (as is the case with tawarruq), ibn Qudama, a classical Hanbali scholar approved of this contract. Subsequently, Hanbali jurists divulged into tawarruq deliberations and declared it permissible on the basis that it was not contained in the hilah for riba. Ibn Al Abidin, a prominent Hanafi scholar later reaffirmed the permissibility of the tawarruq contract and distanced it from the 'inah contract which was condemned. However, Ibn

International Journal of Management and Applied Research, 2020, Vol. 7, No. 2 
Taymiyyah along with Ibn Qayyim both notable scholars diverged from the Hanbali's majority approval of tawarruq and subsequently disallowed it and referring to it as a hilah (ruse) comparable to the inah contract (Al-Zuhayli, 1989).

From the Shafi'i' jurists point of view, although not explicitly mentioned among their treaties, it is accepted due to the separation of contracts between the two transactions which are considered to be independent and separated from each other unless there is a condition stipulated in the contract for the second trading. Imam Shafi'i Explained when clarifying inah's impermissibility that it is not haram if someone sells his property that he purchased on loan or deferred payment on cash basis as long as he sells it to a third party other than the seller (Al-Shafi'i, 2001, Vol. 3, p. 79).

The Maliki school of thought also regarded tawarruq as being permissible. Whilst Imam Malik is known to have discussed the impermissibility of inah, he did not explicitly discuss the tawarruq contract. However, further on, Maliki scholars and proponents did discuss the permissibility of tawarruq under the umbrella of inah hence specifying tawarruq as the exception for the impermissibility of 'inah (Al Qarafi, 2001).

\section{The use of Tawarruq in contemporary Islamic banking}

Majority of the contemporary scholars concur with the view of the classical scholars on the permissibility of classical form of tawarruq. With the modernisation and subsequent transformation of the tawarruq contract to fit in with the evolving financial system, scholars have differed on the modern tawarruq practice. The Majma'a Fiqh al Islami in 1998 declared tawarruq practice as permissible as long as the buyer does not resell (either directly or through an intermediary) the commodity to the original seller. However, the same council subsequently in 2003 concluded that the tawarruq contacts being practiced by the banks under its investigation at the time was impermissible and was then classified as being organised tawarruq. The basis of their disapproval was the inclusion of the wakalah concept to re-sell on buyer's behalf, non-possession of the commodity by the buyer and lastly the fictitious nature of the whole process and paperwork to cover the ruse.

The Shariah Advisory council of Malaysia's central bank deemed tawarruq as permissible (Bank Negara Malaysia, 2010, pp. 94-96). In their view, tawarruq is a trade contract, and its permissibility is grounded in the views of Hanafi, Hanbali and Syafii schools of thought.

In 2006, Accounting and Auditing Organization for Islamic Financial InstitutionAAOIFI's Shari'ah Board resolved that the adaptation of Tawarruq principle in contemporary Islamic banking is subjected to strict controls and restrictions (Mohamad and Ab Rahman, 2014). Subsequently in 2009, the Organization of Islamic Cooperation Fiqh Academy has resolved that the organized Tawarruq is prohibited but maintained the permissibility of tawarruq fiqhi (Dusuki, 2010).

Commodity murabahah transaction is a common term used in commodity market to denote tawarruq (Ismail et al., 2016). The common commodity used in Malaysia is

International Journal of Management and Applied Research, 2020, Vol. 7, No. 2 
Crude Palm Oil (CPO) made available by Bursa Suq al-Sila' (BSAS). The tawarruq structure shown in Figure 1 has raised controversy by scholars due to the contravention of the current application that has significantly diverted away from the tawarruq contract that was approved by the classical scholars (Mohamad and Ab Rahman, 2014). The implementation has been questionable due to the infraction of various shariah principles - Dusuki (2010) points out several issues in this respect which include issues relating to the commodities used in the contracts, possession and delivery, bay al 'inah and agency issues.

\section{Figure 1: Organised tawarruq structure}

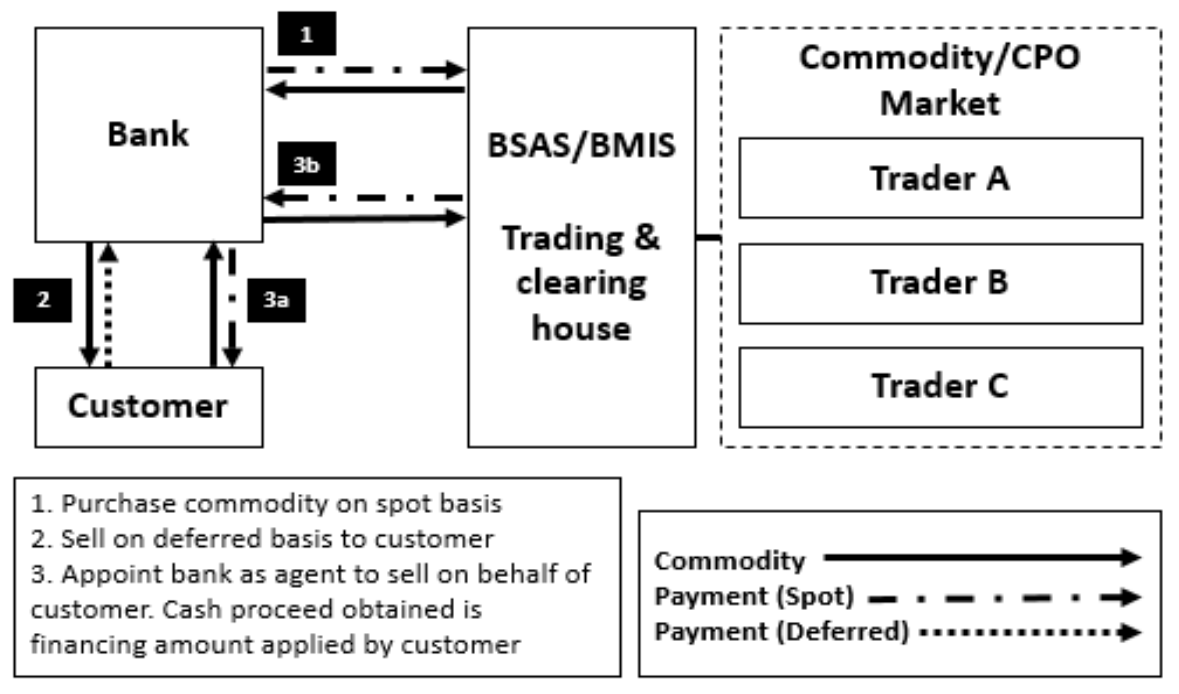

Source: Authors'own

Firstly, the commodities used must have some valid and genuine use in the market for the respective buyers. Basically, this infers that they should have some sort of value to the market and have economic value. Failure of the above will deem the contract as invalid. It has been observed that a significant proportion of the commodities used for modern tawarruq practices (organised tawarruq) uses commodities that are of unsatisfactory economic value as the underlying commodity for use of this transaction. Furthermore, the re-usage of commodities was another concern and the lack of mechanisms and oversight to guarantee that this would not take place added to these concerns.

On matters relating to possession and delivery, the commodity sold must both exist and be in possession of the seller for the transfer of ownership to the buyer and therefore to maintain validity of the sale. Moreover, the buyer should take possession of the commodity or at a minimum be able to access the commodity that he now has ownership of. This is lacking in the current practice where there are cases of explicit restrictions placed on delivery of the commodity.

Moreover, the modern practice has been faulted by some for operating netting transactions between different locations where the commodities are stored in order to

International Journal of Management and Applied Research, 2020, Vol. 7, No. 2 
appear to have followed due process and therefore appear to be valid. This is seen as a hilah (ruse) practiced via an electronic demarcation system for labelling and delabelling ownership of the commodities in the stores. This indicates that the original seller and the final buyer collude which also infers that this is a ploy to bypass the 'inah contract. This was also indicated in guidelines by AAOIFI on tawarruq released in 2008.

The guidelines also highlight another issue that is of concern to scholars regarding the modern tawarruq practice which is the use of agency or wakalah in the tawarruq structure. The guideline emphasises the need for the client to resell the commodity rather than the bank acting on his behalf. This is clearly lacking in the current structure as neither the banks nor the clients seeking financing would want this responsibility to be passed on to the client for various reasons, namely time commitment and opportunity cost.

Notwithstanding the controversies of tawarruq, the use of tawarruq as a liquidity management remains widespread. According to Visser (2019), one attractive feature of tawarruq is its ease of use which distinguishes it from other time-consuming Islamic contracts. Similarly, Mohamad and Ab Rahman (2014, p. 494) noted that tawarruq is commonly used in corporate financing because "it provides a clean-cut process and is able to avoid any regulatory procedure and condition pertaining to the asset where applicable". In addition to personal finance and corporate financing, tawarruq can also be used to address liquidity needs of Islamic financial institutions (Ismail et al., 2016).

It is important to scrutinize the implementation of Crude Palm Oil (CPO) Commodity structure by BSAS, especially in regard to criticism of the structure. BSAS (formerly known as Commodity Murabaha House) was launched in 2009 by Bursa Malaysia (the Malaysian stock exchange) in collaboration with the central bank and the securities commission to facilitate liquidity management and financing primarily by Islamic banks using the tawarruq contracts via murabaha and musawamah arrangements. It was part of the initiatives by the Malaysia International Islamic Financial Centre (MIFC) to try and propel Malaysia towards being a global hub for Islamic finance. It served as a multi-commodity and multi-currency end to end shariah compliant trading platform which was crucial for the development and sustainability of Islamic Finance Industry in Malaysia.

Rather than banning the use of the tawarruq contract, Malaysia set up an electronic, web-based trading platform. The platform recognises and validates ownership through the means of electronic certificate (Ahmad et al., 2017). The platform, which initially used CPO, then subsequently added plastic resin to the tradable commodities, conducts regular shariah audits on the suppliers of those commodities to ensure that their practices are genuine, that they have tangible commodities and in sufficient quantities to supply the banks. The exchange also takes on the position of the counterparty thus reducing the counterparty risk faced by the banks.

Figure 2 illustrates BSAS Tawarruq mechanism. The first stage involves the bids and offers by banks and CPO suppliers respectively prior to market opening, orders are

International Journal of Management and Applied Research, 2020, Vol. 7, No. 2 
randomised and when the market opens the BSAS engine matches the orders and trade commences with the CPO supplier then selling the commodities ordered to the banks via a broker (broker A).

Figure 2: BSAS Tawarruq Mechanism

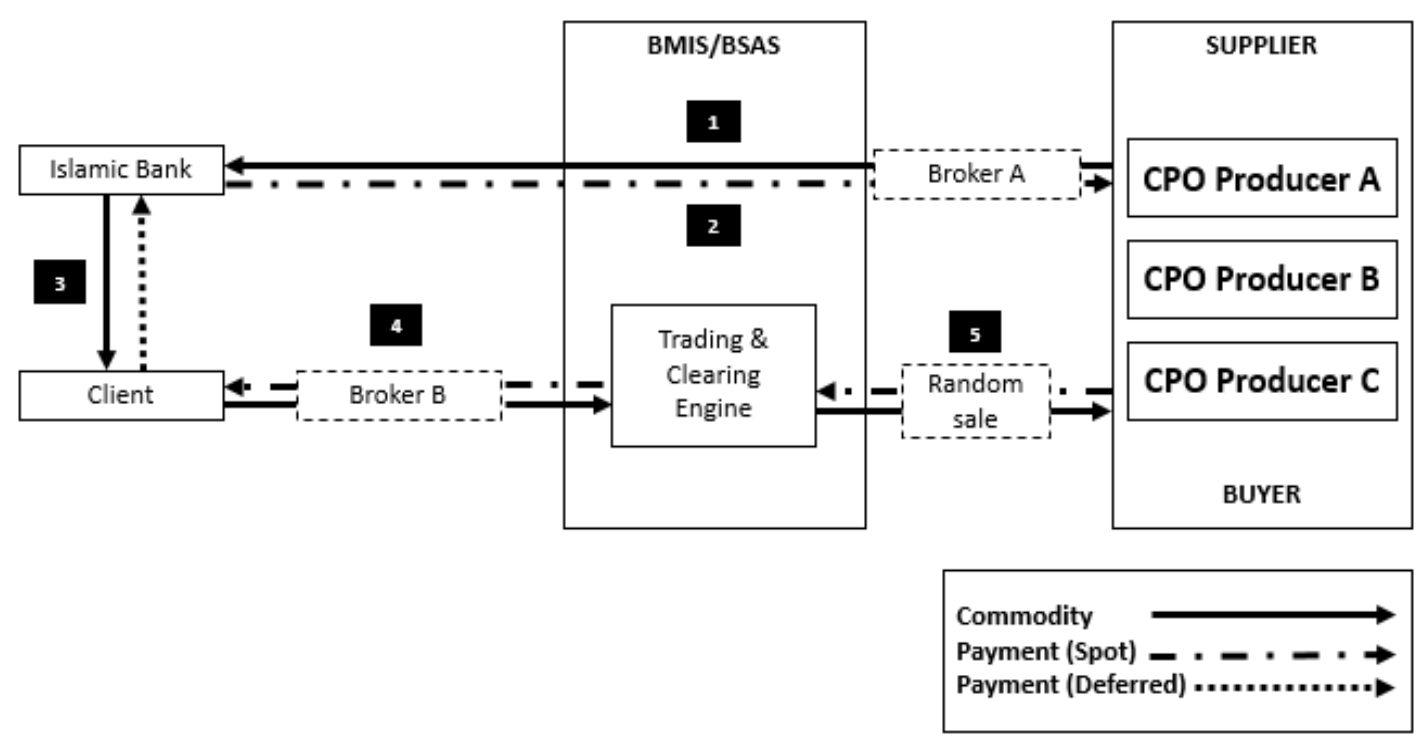

Adapted from: Ahmad et al. (2017, p.40)

The second stage involves the first bank (Bank A) crediting the Bursa Malaysia Islamic Service's (BMIS) account after BMIS ensures the delivery and hence performance of the relevant supplier. Thereafter, in the third stage, assuming that it's a financing contract, the bank sells the commodity to the client on a deferred basis via a murabaha contract after which the ownership details of the commodity are changed by Bursa Suq al-Sila (BSAS) to reflect this sale transaction. During the next stage, the client then through an agent of the same bank (or directly) sells the commodity to BMIS at the market price (lower than agreed deferred price) and receives payment from BMIS through the bank (by debiting BMIS's account and crediting the client's account) and transfers the commodity ownership to BMIS. In the fifth and final stage, the commodity is sold to the suppliers randomly based on the bids. The supplier (after receiving ownership) may re-offer the commodity to the BSAS market for further trading as long as they are free from liability.

The BSAS mechanism discussed above demonstrates the effort by the relevant authorities to try and find solutions to the disputes and concerns raised by the scholars on organised tawarruq. On the issue of the use of substandard commodities, BSAS uses CPO and plastic resin which are both valuable commodities with the former especially being of significant value and importance to Malaysia. The provision of ecertificates to the clients tackles the issue of ownership recognition and verification. However, the sheer volumes of transactions required especially with banks increasing their reliance on tawarruq contracts on majority of their financing and liquidity

International Journal of Management and Applied Research, 2020, Vol. 7, No. 2 
applications causes skepticism as to the ability of maintain sufficient stocks of the commodities to meet this increasing demand.

Furthermore, Dusuki (2010) points out that although BSAS allows for the delivery of the commodity which tackles the issue of delivery discussed earlier, there is a processing fee for delivery that the client will be subjected to after he indicates his intention to physically take possession. This, according to scholars, raises doubts on the sincerity of the contract as the 'delivery processing fee' should essentially be included in the selling price where they explain that typically a sale involves both the intention to deliver and subsequent delivery. This increased cost will discourage delivery which goes against the essence of the classical tawarruq contract. Some contemporary writers argue that constructive possession is taken through the relevant stages and so the BSAS platform is unable to resolve the issue of agency (tawkeel) in the modern tawarruq contracts employed by banks and which was rejected by the AAOIFI guidelines. This however cannot be attributed to the failure of the platform but rather to the banking practices and the majority of the clients' unwillingness to take responsibility. Having said that, those who argue in favour of organised tawarruq claim that firstly the agency contract on its own right is completely valid and the client seeking financing is at liberty of appointing any party as his agent including the bank.

Transitioning from the discussion of the CPO tawarruq implementation, this paper scrutinizes the offering of the As-Sidq tawarruq platform by Sedania As-Salam. In terms of transactional flow, the structure does not differ much from BSAS; this is seen below:

Figure 3: Airtime Tawarruq Mechanism

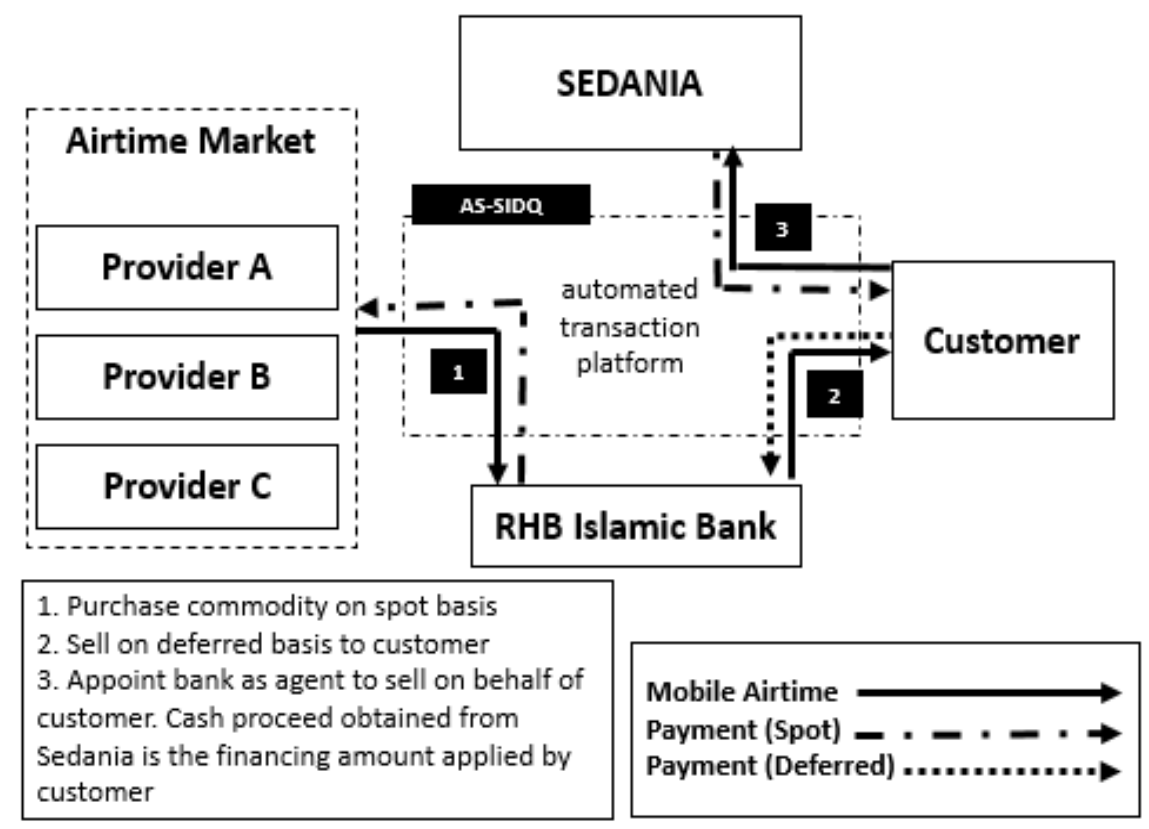

Adapted from: Ismail et al. (2016, p.391)

International Journal of Management and Applied Research, 2020, Vol. 7, No. 2 
The use of airtime as asset or commodity has the following advantages: airtime is invisible and non-perishable, and it has no expiry date but has a long shelf life. Such traits significantly lower the cost of delivery, storage, and maintenance compared to tangible assets. Moreover, airtime is connected to real economy because each serial number represents usage of airtime (Ismail et al., 2016) while the value of airtime credit is not affected by daily fluctuation in currency exchange.

However, the use of airtime as commodity is not without limitations: firstly, the AsSidq tawarruq platform has high transaction cost; secondly, the aggregate amount might not be able to absorb the high liquidity needs of corporations despite of high demands for airtime credit; thirdly, airtime might not reach the market for real economy (Ismail et al., 2016).

Arguably, the trait of stable airtime value could be potentially negative as it removes the element of ghurm that should be present in all sale transactions. This may expose the transaction to shariah non-compliance risk. Additionally, like the structure seen in BSAS, the structure proposed by As-Sidq tawarruq platform involves the appointment of bank as agent to the customer at the stage of reselling, which constitutes an agency problem.

\section{Recommendation: Smart Tawarruq}

It is contemplated that in this era of Fintech, tawarruq can be potentially offered using smart contracts. Fintech can be explained as the application of technology within the financial industry. Smart tawarruq structure will use blockchain technology and smart contracts reducing the costs of the transaction and the number of intermediaries involved.

A blockchain is a distributed ledger technique in which all the members participating in the network share transaction information among themselves. As such, blockchain can be described as a distributed database that maintains a constant growing list of data records that cannot be tampered and revised even by operators of the data store's nodes (Bashir, 2017). The blockchain is therefore a distributed or peer-to-peer public ledger that consists of "blocks" maintained by a distributed computers network which contain multiple verified transactions record without a central authority or third-party intermediary (Niforos et al., 2017). A peer-to-peer, commonly written as P2P, is a description of a decentralised communication model via computer software that enables linkup of commercial and/or private users of the internet to communicate or share resources with the same capabilities and any party can initiate a communication session.

The blockchain comprises of three essential elements as follows: a transaction, a transaction record and a system for verification and storage of the transaction. Application generates the blocks and records information as to time and the manner the transaction occurs in sequence. Each block comprises of a secured hash, generated while taking into account the index, timestamp, data inside the block and hash of previous block. This manner of design renders a blockchain capable of auditing. Thus, after a block has been verified and added to the blockchain, any alteration to that block

International Journal of Management and Applied Research, 2020, Vol. 7, No. 2 
would produce a new hash which will be inconsistent with the hashes that precede and would be rejected. The block sequentially maintains data of all transactions that have occurred in the chain, and keeps irreversible time-stamped record of every transaction replicated on servers across the globe (Peters and Panayi, 2015).

The blockchain structure provides an immutable record of transaction via a network of devices that establish a global cryptographic peer-to-peer trust and a permanently unalterable means of ascertaining the record (Muneeza and Mustapha, 2019). These are substituted with automation which verifies each and every component to ensure and safeguard compliance with all requirements. The blockchain technology offers an open source, decentralised, peer-to-peer network that enables secure real-time payment services, enhancing traditional commerce. In this sense, blockchain can be used in Islamic finance and banking to improve efficiency and transparency.

The blockchain technology has made possible the creation of a platform that makes not only create cryptocurrency such as bitcoin but also recording of values involving currency and assets through its digitally decentralised ledger. As requirements of Shariah, the blockchain's inherent disclosure, transparency and enhancement of trust in transfer and exchange can be considered particularly beneficial.

Ethereum is a blockchain platform optimized for smart contracts and there are examples of insurance contracts, marriage report and smart grid billing based on the Ethereum platform in the smart contract (Niforos et al., 2017). In addition to Bitcoin blockchain, an Ethereum blockchain the transaction list and the most recent state in addition to the creation of blocks. For every transaction in the transaction list, the new state is created by applying the previous state. In particular, if smart contracts are introduced in full impulse, they will be rapidly applied to the fields of various transactions in financial department, which are connected largely to the public. Therefore, the blockchain, as a closed-type distribution ledger, is expected to become the engine of future finance (Yoo, 2017). In 2019, Bursa Malaysia (Stock Exchange of Malaysia) completed its first securities borrowing and lending Proof of Concept (SBL POC) blockchain technology solution. According to the official statement released by Bursa Malaysia, the SBL POC was a successful test of a blockchain-driven lending pool that can improve efficiencies and build transparency (Bursa Malaysia, 2019).

Smart contracts are basically self-executing digital contracts in which the terms of the contract are electronically coded and execute only if stipulated conditions are met (Bashir, 2017; Muneeza and Mustapha, 2019; Niforos et al., 2017; Yoo, 2017). With this mechanism in place, when a client/customer comes to an Islamic bank for tawarruq financing, the bank and the customer do not need to physically come to a branch of the bank to meet or undertake rigorous legal documentation via their lawyers.

The smart contracts are applied to real estate transactions, legal contracts and financial trade whereby conditions and contents of the transactions are registered, then relevant laws and procedures are automatically applied and the result is notified to the transaction parties. Smart contract would add to the optimism of the prospect of AI of using blockchain to initiate, perform and conclude murabahah transactions by Islamic banks. With contract recorded in public ledger and given the anonymity of parties, the

International Journal of Management and Applied Research, 2020, Vol. 7, No. 2 
conditions of a smart contract are always met with certainty leaving no chance for any of the parties to blame another of wrong by omission or commission. In effect, the Smart contract protocol sets up a computer operation that is condition-driven, so that transactions can only be possible after all requirements for such transactions, including Shariah-compliance, are accordingly satisfied. Assuredly then, this mechanism of contract eliminates uncertainty and confusion arising from parties' default. Smart tawarruq is underpinned by smart contracts which are expected to simplify physical and visual transactions and reduce transaction costs against existing forms of transactions based on physical exchanges.

Along these lines, rules of Shariah governance can as well be programmed into the smart contract that will enable the smart tawarruq. This can be automated or written into the manuals and guidelines published by authorities, Bank Negara Malaysia, regulators, and all necessary stakeholders forming the transaction network on blockchain. These nodes will then be enabled to validate transactions and append compliant blocks in the blockchain. Accordingly, respective regulators, whose approval or endorsement is required for a particular smart contract-based product or service, can be made part of the protocol to oversee and/or approve of any particular block to join the blockchain. In this manner, any transaction that is not Shariah compliant in accordance with the protocols cannot be verified and would be out wholly rejected as unqualified to join the block. If the fiat currency can be issued through the blockchain, then the code can be embedded into the act of issuing the fiat currency through smart contract programming. Figure 4 illustrates the proposed Smart Tawarruq model.

Figure 4: Proposed Smart Tawarruq Model

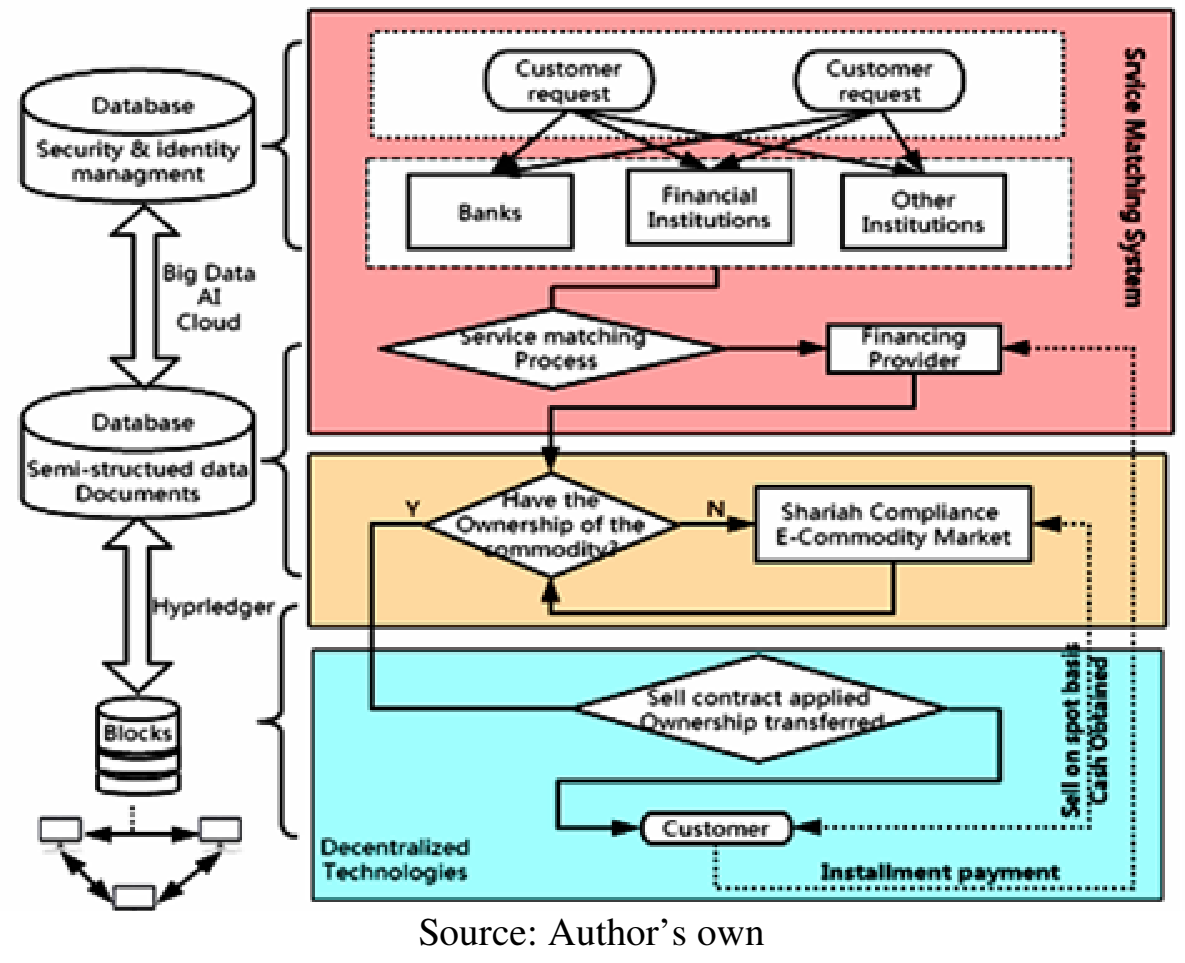

International Journal of Management and Applied Research, 2020, Vol. 7, No. 2 
In the model illustrated in Figure 4, various fintech mechanisms like Big Data and AI are integrated with the pre-stored corporate or individual ID, creditworthiness of the client will be evaluated in advance for parties applying any kind of financing. Unlike the traditional contract where the credit of the client is needed with a third-party guarantee, here, the chain stored date in each block is real and transparent, the recorded content cannot be changed, no further credit investigation is required in which it can significantly reduce the credit risk for the financing provider. Secondly, the recorded message in the smart contract blockchain is not allowed to be modified, the history information is traceable so that double secured for the financing provider which extra constrain will be enforced for applicants because of the high cost of falsifying or in case of default. As per design of the model is to solve the current monodirection of tawarruq products provided by banks, the designed model gives an open market click for banks, institutions and individuals to offer financing. The service matching system evaluate bilaterally for a best matching in terms of reducing credit risks, liquidity risks and shariah compliance risk. For customers, they can choose among the matchings with the factors like best service, or for institutions choose to provide financing for the customer for the best credit rating factor.

After the matching process, smart contract will be executed for the rest of processes monitored by the decentralized blockchain system which is able to effectively reduce the cost assigned by the traditional financing services. Currently, the tawarruq application are still manual and the processes are time consuming and costly. Blockchain system and smart contract has the potential to effectively and significantly improve the overall process.

The next process, the terms and conditions of Islamic finance products need to be specified in legal documents and with the correct order to be executed in compliance with Shariah. Thus, a strict evaluation of holding of the ownership of the shariah compliant commodity will be executed or else trading from the shariah compliance Ecommodity market is necessary for obtaining the ownership. The semi-structured data will be required in the system and the ownership will be presented in form of token in the blockchain as a must requirement to proceed with the following sell contract.

In the last stage, how customers deal with the commodity is their personal choice, he can sell directly in the commodity market on spot basis to get cash payment or he can consume it for other purpose. In the end, the instalment payment to the financing provider will be based on agreement, and the payment will be executed by smart contract in a pre-agreed manner.

In the structure, notarized information and other information need to be stored on the blockchain. Since the notarized information comes from the centralized department, it cannot completely eliminate the fraud but it can greatly reduce the difficulty of the company or individual that needs to be verified. The distributed storage system also allows important files encrypt in different parts of the world, stimulated by tokens. The settlement time on the blockchian by using tokens for cross-border financing is within a short period of time, far exceeding the current mainstream bank cross-border

International Journal of Management and Applied Research, 2020, Vol. 7, No. 2 
transfer, especially the transfer between some small countries, often takes more than a week.

Compared with classical tawarruq, smart tawarruq offers greater level of conformity to shariah principles. For instance, the issue of duplicated assets involved in a classical tawarruq structure could be eliminated under the structure of smart tawarruq. However, it shall be kept in mind that in structuring the smart contract for all Islamic financial contracts, it is essential to comply with shariah requirements as well as domestic legal system and international trade law. Further research is required to understand the feasibility of smart tawarruq.

Table 1 illustrates the differences and similarities between the current and proposed structures. The advantage of the proposed structure is the elimination of intermediary or broker. The customer and the bank can directly deal with suppliers via Ecommodity market. In this way, transactions can be made more securely and costeffectively. The dual agency role played by the bank will also be eliminated under the proposed structure, thereby making the transaction Shariah compliant.

Table 1: Comparison between current and proposed structure

\begin{tabular}{|c|c|c|}
\hline & Current structure & Proposed structure \\
\hline $\begin{array}{l}\text { Customer } \\
\text { request }\end{array}$ & \multicolumn{2}{|c|}{ Customer requests for financing via Tawarruq. } \\
\hline Verification & \multicolumn{2}{|c|}{$\begin{array}{l}\text { The bank manager verifies all documentation, ensuring } \\
\text { all documents meet regulatory requirements. }\end{array}$} \\
\hline $\begin{array}{l}\text { Spot } \\
\text { purchase }\end{array}$ & $\begin{array}{l}\text { Bank purchases commodity on spot } \\
\text { from commodity broker } 1 .\end{array}$ & $\begin{array}{l}\text { Bank purchases commodity on spot } \\
\text { from E-commodity market. }\end{array}$ \\
\hline $\begin{array}{l}\text { Deferred } \\
\text { payment }\end{array}$ & N/A & $\begin{array}{l}\text { Bank sells the commodity to } \\
\text { customer on a deferred payment } \\
\text { basis (cost plus profit). }\end{array}$ \\
\hline $\begin{array}{l}\text { Agent vs. } \\
\text { Platform }\end{array}$ & $\begin{array}{l}\text { Customer authorises the bank as an } \\
\text { agent. }\end{array}$ & $\begin{array}{l}\text { Customer sells the commodity on } \\
\text { spot to E-commodity market. }\end{array}$ \\
\hline $\begin{array}{l}\text { Additional } \\
\text { broker }\end{array}$ & $\begin{array}{l}\text { The bank as agent sells the } \\
\text { commodity to broker } 2 \text { on spot. }\end{array}$ & N/A \\
\hline $\begin{array}{l}\text { Additional } \\
\text { step }\end{array}$ & Broker 2 pays the bank on spot. & N/A \\
\hline $\begin{array}{l}\text { Payment to } \\
\text { customer }\end{array}$ & Bank pays customer. & $\begin{array}{l}\text { E-commodity market pays to the } \\
\text { customer on spot. }\end{array}$ \\
\hline $\begin{array}{l}\text { Smart } \\
\text { contract }\end{array}$ & $\begin{array}{l}\text { Customer pays to bank by instalment } \\
\text { via ordinary means. }\end{array}$ & $\begin{array}{l}\text { Customer pays to bank by instalment } \\
\text { via smart contract. }\end{array}$ \\
\hline
\end{tabular}

\section{Conclusion}

Although tawarruq is a controversial contract from shariah perspective, it is extensively applied in Islamic banking Malaysia today. With the unfolding digital age, tawarruq transactions need to be upgraded accordingly and in line with modern financial innovation. Islam generally does not frown at innovation in non-ritual activities generally unless such innovation contradicts a clear Shariah provision. Blockchain technology is one such innovations that does not contradict Shariah but

International Journal of Management and Applied Research, 2020, Vol. 7, No. 2 
rather aligns with Shariah as it enables and allows all parties involved in an Islamic finance transaction to hold and make transactions in a completely transparent manner, irrespective of the fact that the parties involved are strangers or do not know one another. The Blockchain technology takes care of trust aspect in dealings by rendering transactions impersonal via smart contracts. This reduces transactions costs significantly in addition to incorporating Islamic values of transparency, equality, justice into finance. Further, adopting the blockchain technology to reinvent murabahah facilitates Islamic finance acclimatize to the changing scene of contemporary economic and financial dealings. The smart tawarruq will enable transactions to be conducted in a more reliable manner, paving way for regulators to exercise oversight function with assured Shariah governance.

Despite the fact that the blockchain technology and smart contract present tremendous benefits and opportunities for developing murabahah and Islamic finance in general, it also presents some challenges. The technology faces regulatory constraints due to absence of appropriate legislations, coupled with lack of expertise and skills among Islamic finance players. At the same time, being a new technology, the blockchain presents some technical issues which can only be overcome over time with development of the technology, result-oriented researches and decisive regulatory actions.

It is evident from this paper that there is a lot of potential in applying blockchain and smart contract to murabahah. However, to formulate or devise this smart tawarruq structure research needs to be conducted by respective Islamic banks. It is essential to note that moving away from tawarruq-based products is often advised by the Shariah scholars. However, innovative Islamic financial instruments need to be introduced to the industry. Consequently, as long as tawarruq is utilized in the Islamic banking industry, its current application can be enhanced with blockchain and smart contract. Undoubtedly, the blockchain technology will be integrated into Islamic finance as it is anticipated that more Islamic financial products and services fintech would be floated using the technology in the near future. With the help of the blockchain technology, smart tawarruq may be the future formulation of tawarruq in the in the industry.

\section{References}

1. Ahmad, E. F.; Shihama, M.; Mohamad Tarmizi, N. A.; Jibril, S. M.; Djama, S. I. and Muneeza, A. (2017), "Tawarruq as a Product for Financing within the Islamic Banking System: A Case Study of Malaysian Islamic Banking System", International Journal of Management and Applied Research, Vol. 4, No. 1, pp. 3143. https://doi.org/10.18646/2056.41.17-004

2. Alkhamees, A. (2017), "Tawarruq as a Case Study of Creative Sharī' ah Compliance", in: Allen, D. (ed), A Critique of Creative Shari'ah Compliance in the Islamic Finance Industry, UK: Brill. pp. 67-86. https://doi.org/10.1163/9789004344433_005

International Journal of Management and Applied Research, 2020, Vol. 7, No. 2 
3. Al-Shafi'i (2001), Kitab al-Umm, edited by Rifat Fawzi Abd al-Muttalib. 11 Vols. Al-Mansura: Dar al-Wafa'.

4. Al-Zuhayli, W. (1989), Al-Fiqh al-Islami wa Adillatuhu, $3^{\text {rd }}$ ed., Beirut: Dar alFikr.

5. Bank Negara Malaysia, (2010), Shariah resolutions in Islamic finance, $2^{\text {nd }}$ ed., Kuala Lumpur: Bank Negara Malaysia [Online] available from:

http://www.bnm.gov.my/microsite/fs/sac/shariah_resolutions_2nd_edition_EN.pdf [Accessed on 6 January 2017].

6. Bashir, I. (2017), Mastering Blockchain, Birmingham: Packt Publishing.

7. Bursa Malaysia (2018), Securities borrowing and lending: the blockchain path to building operational efficiencies, [Online] Available from:

https://www.bursamalaysia.com/cn/about_bursa/media_centre/securitiesborrowing-and-lending-the-blockchain-path-to-building-operational-efficiencies [Accessed on 3 May 2020].

8. Dusuki, A. W. (2010), "Bursa Malaysia's Suq Al-Sila'(Commodity Murabahah House) as an Alternative Platform for Tawarruq Transaction", The Journal of Muamalat and Islamic Finance Research, Vol. 7, No. 1, pp. 147-167.

9. Ismail, A.G., Nik Abdul Ghani, N.A.R. and Mat Zain, M.N. (2016), "Tawarruq time deposit with wakalah principle: an option that triggers new issues", International Journal of Islamic and Middle Eastern Finance and Management, Vol. 9 No. 3, pp. 388-396. https://doi.org/10.1108/IMEFM-05-2014-0048

10. Majma' al-Fiqh al-Islami al-Duwali (2009), "al-Tawarruq, Haqiqatuh, Anwa'uh (al-Fiqhi al-Ma'ruf wa al-Masrifi al-Munazzam)", al-Qararat wa al-Tawsiyat, 19th Seminar, Resolution No. 179 (19/5), pp. 12-13.

11. Mohamad, N. and Ab Rahman, A. (2014), "Tawarruq application in Islamic banking: a review of the literature", International Journal of Islamic and Middle Eastern Finance and Management, Vol. 7 No. 4, pp. 485-501. https://doi.org/10.1108/IMEFM-10-2013-0106

12. Muneeza A. and Mustapha Z. (2019), "Blockchain and Its Shariah Compliant Structure", In: Billah M. (eds) Halal Cryptocurrency Management, Cham: Palgrave Macmillan, pp. 69-106. https://doi.org/10.1007/978-3-030-10749-9_6

13. Niforos, M.; Ramachandran, V.; Rehermann, T. (2017), Block Chain: Opportunities for Private Enterprises in Emerging Market, Washington, D.C.: International Finance Corporation, available from: https://openknowledge.worldbank.org/handle/10986/28962 [accessed on 1 Aug 2018].

International Journal of Management and Applied Research, 2020, Vol. 7, No. 2 
14. Peters, G.W. and Panayi, E., (2015), "Understanding Modern Banking Ledgers through Blockchain Technologies: Future of Transaction Processing and Smart Contracts on the Internet of Money", In: Tasca, P.; Aste, T.; Pelizzon, L.; Perony, N. (eds) Banking Beyond Banks and Money. Cham: Springer, Banking Beyond Banks and Money, pp. 239-278. https://doi.org/10.1007/978-3-319-42448-4_13

15. Yoo, S. (2017), "Blockchain based financial case analysis and its implications", Asia Pacific Journal of Innovation and Entrepreneurship, Vol. 11, No. 3, pp. 312321. https://doi.org/10.1108/APJIE-12-2017-036

16. Visser, H. (2019), Islamic Finance: Principles and Practice, Third Edition, UK: Edward Elgar Publishing.

International Journal of Management and Applied Research, 2020, Vol. 7, No. 2 